\title{
Selecting Biofuel Obtained from Sunan Pecan Oil for Diesel Engine Fuel
}

\author{
Mas Ade Moetangad Kramadibrata ${ }^{1}$, Sarifah Nurjanah ${ }^{1}$, Mimin Muhaemin ${ }^{1}$, Efri Mardawati ${ }^{2}$, Totok Herwanto ${ }^{1}$ \\ Handarto $^{1}$, Sari Narulita Rosalinda ${ }^{1}$, Wahyu Darajat ${ }^{3}$ and Fathia Emma Putri ${ }^{1}$ \\ 1. Dept. Agriculture Engineering and Biosystem, Faculty of Agro-Industrial Technology, Universitas Padjadjaran, Bandung 40115, \\ Indonesia
}

2. Dept. Agro-Industrial Technology, Faculty of Agro-Industrial Technology, Universitas Padjadjaran, Bandung 40115, Indonesia

3. Dept. Agro-Technology, Faculty of Agriculture, Universitas Padjadjaran, Bandung 40115, Indonesia

\begin{abstract}
In search of biofuel as sustainable energy alternatives for anticipating the gradually decreasing fossil fuel that surely would affect engine performances of industrial machinery as a whole, the research herewith was aimed to confirm that oil obtained from compressing Sunan pecan seeds (Reutalis trisperma) is the suitable unedible raw oil material to be processed. By carrying out esterification and transesterification processes, the oil became biofuel which consists of various forms of long-chains components of fatty acid methyl ester (FAME). To make it usable for diesel engine, steps of further processes have been done, i.e., purification and fractionation to produce FAME of single fatty acid components as well as selecting them by PROMETHEE method. The result showed that FAME with single unfractionated fatty acid components was closed to diesel oil characteristics and so the most appropriate biofuel for internal combustion engine.
\end{abstract}

Key words: Biofuel, fractionation, single FAME components, PROMETHEE, diesel engine.

\section{Introduction}

The need to explore the potential of biomaterials to replace energy source from fossil due to fossil fuel limitation has become increasingly necessary. One of the bioenergy that can be produced from vegetables and animal triglycerides is biodiesel. Biodiesel has physical properties similar to diesel fuel, therefore it can be used for diesel engines. As a renewable fuel, biodiesel has some advantages compared to petroleum-based diesel, since it is biodegradable and non-toxic, also, it has more favorable combustion emission profile, lower sulfur content as well as lubrication and cleaning machines which are better than diesel fuel $[1,2]$. Some vegetable oils that are usually used as the feedstock of biodiesel are palm oils, soybean, sunflower, rapeseed and jatropha [3-7]. Kemiri Sunan (Reutealis trisperma) oil can be used to

Corresponding author: Mas Ade Moetangad Kramadibrata, professor, research field: agricultural engineering. produce biodiesel as well because its oil content is $50 \%-56 \%$ and the oil cannot be used as oil food due to its poisonous content (alpha oleo stearic acid) [8, 9].

Biodiesel is defined as the mono-alkyl esters, either methyl and ethyl ester of vegetable and animal oils fatty acid. It is produced by transesterification process of triglycerides in the form of fatty acid methyl ester (FAME) or fatty acid ethyl ester (FAEE). Triglycerides are converted into FAME or FAEE and glyceride by alcohol and a strong base catalyst [1, 5, 7]. Biodiesel that is produced from the transesterification process contained more than one ester of fatty acid.

This type of fatty acid esters determined the quality of biodiesel such as oxidation stability, kinematic viscosity, emission, cetane number and energy produced. Biodiesel mostly contains FAME of palmitic acid, stearic acid, oleic acid, linoleic acid and linolenic acid. Palmitic acid ester has the highest cetane number (85.9), while the lowest melting point 
and kinematic viscosity are in the linolenic acid ester $\left(-52{ }^{\circ} \mathrm{C}\right.$ and $3.14 \mathrm{~mm}^{2} / \mathrm{s}$, respectively) [10].

According to the regulation of Directorate General of Oil and Gas No. 978.K/10/DJM.S/2013, Indonesian standard of diesel fuel, cetane number should be more than 48 , and its kinematic viscosity should be 2.0-4.5 $\mathrm{mm}^{2} / \mathrm{s}$ at $40{ }^{\circ} \mathrm{C}$. Based on the research conducted by Knothe [10], fatty acid esters that meet the Indonesian standard characteristic of biodiesel are methyl palmitate and methyl oleate. FAME of Kemiri Sunan contains $12.49 \%$ methyl palmitate, $7.29 \%$ methyl stearate, $15.36 \%$ methyl oleate, $17.05 \%$ methyl linoleate and $45.97 \%$ methyl linolenate. Therefore, in order to meet the biodiesel standard, the purification of FAME from Kemiri Sunan is needed to obtain a high content of methyl palmitate and methyl oleate.

A fraction of component in a liquid material can be separated by fraction distillation. This process is based on different boiling point of each component. The fraction distillation can be used to separate liquid material into many components in one running time. Some factors that influence the fractional distillation process are temperature, pressure, distiller column and reflux $[11,12]$. Boiling point temperature varies for each component, for example, the boiling point at a pressure of $10 \mathrm{mmHg}$ of palmitic acid methyl ester is $330{ }^{\circ} \mathrm{C}$, while oleic acid methyl ester is $350^{\circ} \mathrm{C}$. The pressure in the distillation process influences the stability of fatty acid ester. Usually, distillation was conducted at low pressure $(5-50 \mathrm{mmHg})$ [11]. The right number of reflux is needed to produce the optimal fraction component; if the reflux is too high it will slow the distillation process, and if the reflux is too low, it will produce fraction with low purity.

Research on purification of FAME as biodiesel from Kemiri Sunan has not been done yet. Therefore, this research aimed to study the effect of purification by fraction distillation on the biodiesel component from Kemiri Sunan in order to produce biodiesel that meets the quality standard of biodiesel. The selection of the type of FAME is done by using the
PROMETHEE method, which is how to make decisions based on various criteria that are quantitatively the best (multi-criteria decision making).

\section{Materials and Methods}

The material used in this study is the Kemiri Sunan oil extracted using the pressing method. Biodiesel (FAME) is made through an esterification process using methanol with a sulfuric acid catalyst and transesterification using methanol with $\mathrm{KOH}$ catalyst. Biodiesel fractionation is carried out at three temperature levels, namely each treatment $\mathrm{A}=$ 260-330 ${ }^{\circ} \mathrm{C} ; \mathrm{B}=330-348{ }^{\circ} \mathrm{C}$ and $\mathrm{C}=348-360{ }^{\circ} \mathrm{C}$. The experiment was carried out by three times replication. The parameters used as selection criteria are the yield, kinematic viscosity, cetane number, density, acid number, and flash point. Furthermore, data analysis was carried out using the PROMETHEE method to determine the best raw material.

\section{Results and Discussion}

\subsection{Yields and Characteristics of Kemiri Sunan FAME}

The results showed that not all fractionation temperatures that were set resulted in a fraction of the material but only two fractions were produced. Data on fractionation yields are presented in Table 1.

The yield shows a comparison between the fractions produced after the fractionation process and Kemiri Sunan biodiesel. The results showed that not all ingredients can be fractionated at the specified temperature. Seventy one point eight three percent $(71.83 \%)$ of the material is still left in the fractionation flask. Fractionated material consists of only two fractions, namely in the temperature range $260-330^{\circ} \mathrm{C}$ and $330-348{ }^{\circ} \mathrm{C}$. The one fraction is higher than the two fractions. The characteristics of the two fractions are presented in Table 2 .

Viscosity is a measure of the thickness of a liquid. On biodiesel fuel, the material viscosity affects the operation of the fuel injection device. High viscosity 
Table 1 The yield of fractionation of biodiesel from Kemiri Sunan.

\begin{tabular}{lll}
\hline Fraction & Yield & Standard of deviation \\
\hline Fraction 1 & 16.08 & 0.42 \\
Fraction 2 & 12.10 & 0.80 \\
No fraction & 17.63 & \\
\hline
\end{tabular}

Table 2 Characteristics of fractionated Kemiri Sunan's biodiesel.

\begin{tabular}{|c|c|c|c|c|c|}
\hline \multirow{2}{*}{ Parameter } & \multirow{2}{*}{ Unit } & \multirow{2}{*}{$\begin{array}{l}\text { Standar Nasional Indonesia } \\
\text { (SNI) 04-7182-2006 }\end{array}$} & \multirow{2}{*}{ Biodiesel } & \multicolumn{2}{|c|}{ Fractionation } \\
\hline & & & & Fraction 1 & Fraction 2 \\
\hline Kinematic viscosity at $40^{\circ} \mathrm{C}$ & $\mathrm{mm}^{2} / \mathrm{dt}(\mathrm{cst})$ & $2.3-6.0$ & $5.3^{*}$ & 2.7 & 3.0 \\
\hline Yield & $\%$ & & 17.63 & 3.55 & 2.52 \\
\hline Cetane number & & Min 51 & 53.9 & 71.5 & 69.73 \\
\hline Mass density & $\mathrm{kg} / \mathrm{m}^{3}$ & $850-890$ & $870^{*}$ & 872 & 882 \\
\hline Acid number & $\mathrm{mg} \mathrm{KOH/g} \mathrm{sample}$ & Max 0.8 & $0.55^{*}$ & 0.3 & 0.7 \\
\hline Flash point & ${ }^{\circ} \mathrm{C}$ & Min 100 & $129.5^{* *}$ & 260 & 288 \\
\hline
\end{tabular}

*[9]; ** [13].

will slow down the flow rate of spraying (atomization) of fuel in diesel motors [7], while viscosity that is too low can cause the injection pump to wear out quickly. To prevent both of these in Standar Nasional Indonesia (SNI) the viscosity value has a certain range (Table 2). With the fractionation process, the value of material viscosity drops from biodiesel that has not been fractionated and is still in the standard range specified in SNI for biodiesel in this case, SNI 04-7182-2006.

Mass density is the ratio between the mass of the material and the volume at a certain temperature. The density can indicate the constituent components of the material. The density will increase with the increase in the length of the carbon chain and the number of double bonds. Fractionation results indicate that the density of the two fractions is not much different from biodiesel, candlenut, but is quite different from Sunan pecan oil. All values of fractionation and biodiesel are included in the above mentioned SNI.

Acid numbers indicate the number of fatty acids contained in the material. The higher the fatty acid shows that the esterification and transesterification process is not perfect, the smaller the acid number, the more complete the esterification and transesterification process. Fractionation results showed that the sample-acid number was quite low and was below the threshold according to SNI.

\subsection{Selection of Biodiesel}

The selection of the best biodiesel used using PROMETHEE visuals with the selected criteria is the yield, cetane number, viscosity, acid number, mass density and flash point. Based on the level of importance, each criterion is given the following weight:

(1) Yield: 3

(2) Cetane number: 2

(3) Viscosity: 2

(4) Acid number: 2

(5) Flash point: 2

(6) Mass density: 1

The results of calculations using visual PROMETHEE as seen in Fig 1 showed that Fraction 1 is the first choice with the highest final value, i.e., value 3 for yield (17.63\%), value 2 for cetane number (53.90), value 2 for viscosity (5.30 cst), value 2 for acid number $(0.55 \mathrm{mg} \mathrm{KOH} / \mathrm{g}$ sample), value 2 for mass density $\left(870 \mathrm{~g} / \mathrm{cm}^{3}\right)$ and value 2 for flash point $\left(129.50{ }^{\circ} \mathrm{C}\right)$.

The PROMETHEE diamond graph as shown in Fig. 2, the position of Fraction 1 lies in the positive zone (green) while Fig. 3 illustrates the PROMETHEE rainbow graph which clarifies the content of Fraction 1 


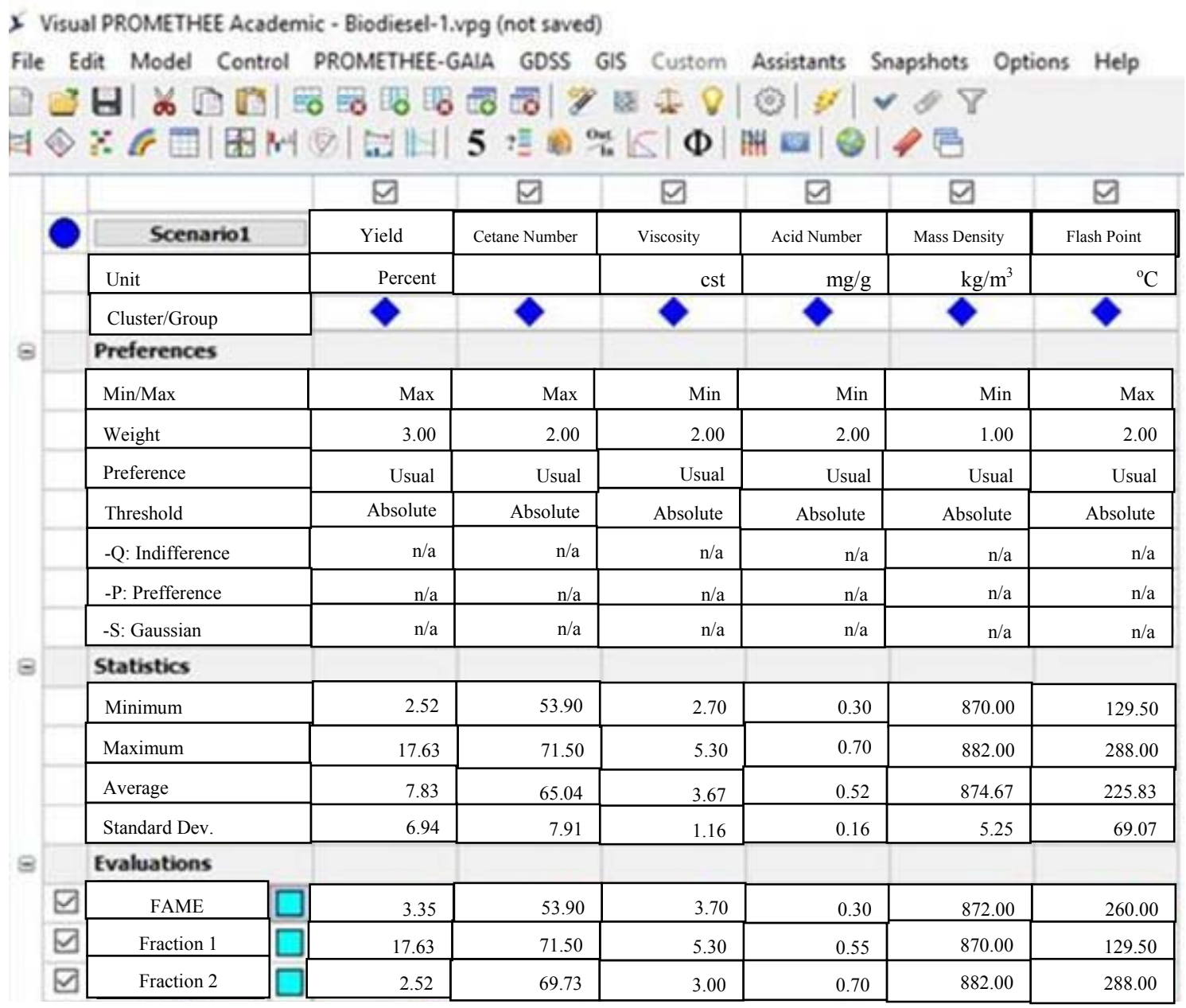

Fig. 1 Forms in visual PROMETHEE.

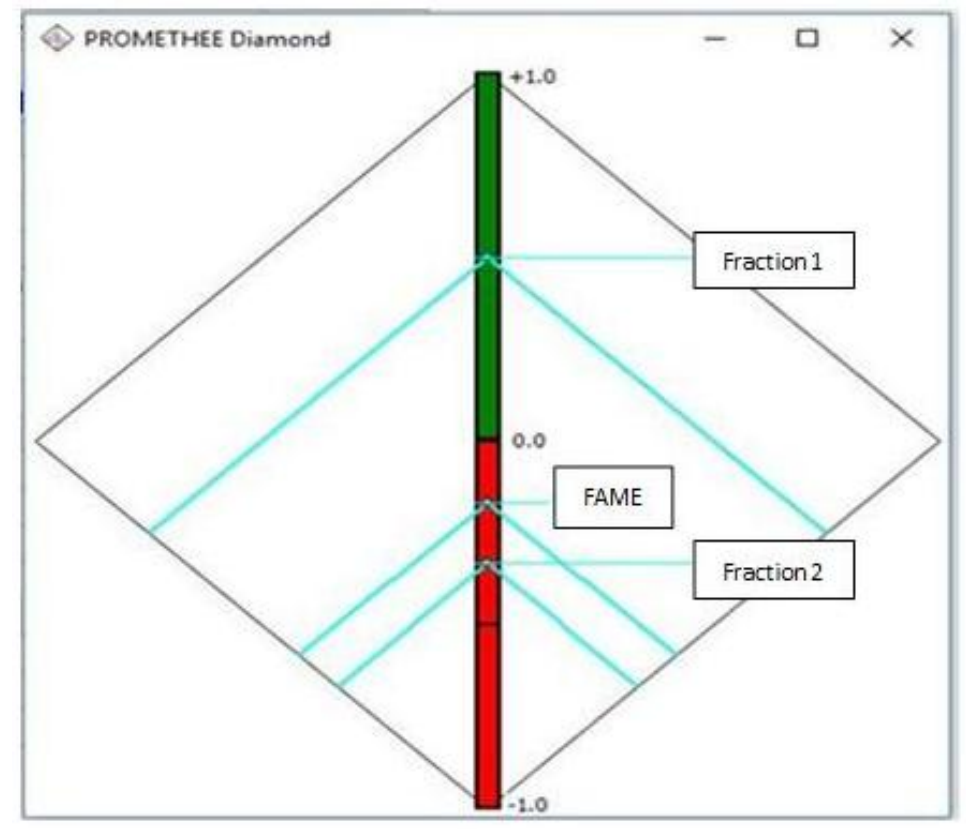

Fig. 2 PROMETHEE diamond graph. 


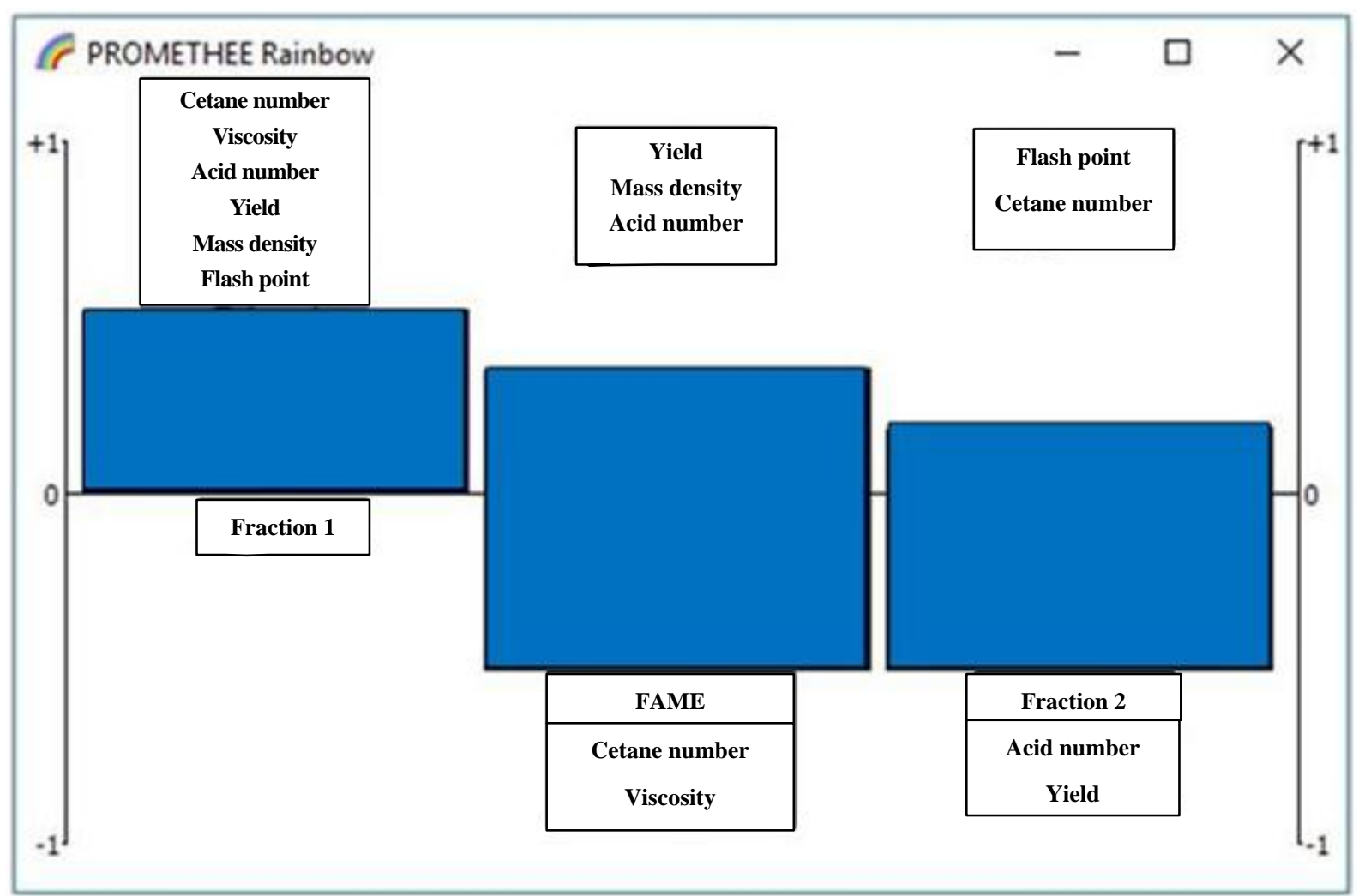

Fig. 3 PROMETHEE rainbow graph.

such as cetane number, viscosity, yield, acid number, mass density, and flash point, emphasizing that this fraction contains the best selected criteria specified for biodiesel. It is shown that the position of Fraction 1 is much higher and lies within the positive zone compared both to FAME and Fraction 2 which lies in the negative zone. Due to the yield, there is relatively high quantity for FAME (17.63\%) and Fraction 1 $(16.08 \%)$ but relatively very low for Fraction 2 $(2.25 \%)$.

The PROMETHEE rainbow graph as shown in Fig. 3 indicated that FAME is not initiated and placed in the second choice position. While Fraction 1 contains the most criteria required for biodiesel which are laid within the positive zone and in facts they are included in SNI 04-7182-2006. Hence, Fraction 1 is the first chosen one.

\section{Conclusions}

The results showed that the selection of biodiesel products which are seen from the yield and physicochemical properties related to the combustion engine (diesel engine), FAME without fractionation is the selected products.

\section{Acknowledgment}

The authors would like to show their appreciation to the research fund provided by the University of Padjadjaran, Bandung, Indonesia, through its Academic Leadership Grant Program.

\section{References}

[1] Al-Zuhair, S. 2007. "Production of Biodiesel: Possibilities and Challenges." Biofuels, Bioprod. Bioref. 1: 57-66.

[2] Knothe, G., Gerpen, J. V., and Krahl, J. 2005. The Biodiesel Handbook. Illinois: AOSC Press.

[3] Manik, Y., and Halog, A. 2012. "A Meta-analytic Review of Life Cycle Assessment and Flow Analysis Studies of Palm Oil Biodiesel." Integrated Environmental Analysis and Management 9 (1): 134-41.

[4] Benavides, P. T., Salazar, J., and Diwekar, U. 2012. "Economic Comparison of Continuous and Batch Production of Biodiesel Using Soybean Oil." 
Environmental Progress \& Sustainable Energy 32 (1): 11-24.

[5] Ghosal, D., and Pradhan, R. R. 2014. "Effects of the Reaction Parameters and Kinetic Study for Preparation of Biodiesel from Karanza Oil." International Journal of Emerging Technology and Advanced Engineering 4 (10): 310-4.

[6] Râducanu, C. E., Pârvulescu, O. C., and Dobre, T. 2017. "Transesterification of Vegetable Oils to Biodiesel in Fixed Bed Catalyst Reactor: Experimental and Modelling." Bulletin of Romanian Chemical Engineering Society 4 (2): 43-51.

[7] Khalid, A., Tajuddin, A. S. A., Jaat, N., Manshoor, B., Zaman, I., Hadi, S. A. A., and Nursal, R. S. 2017. "Performance and Emission of Diesel Fuelled with Preheated Biodiesel Fuel Derived from Crude Palm, Jatropha and Waste Cooling Oils.” International Journal of Automotive and Mechanical Engineering 14 (2): 4273-84.

[8] Supriyadi, S., Purwanto, P., Dwi Anggoro, M., and Hermawan. 2017. "Enhancing Biodiesel from Kemiri Sunan Oil Manufacturing Using Ultrasonics." In Proceeding of E3S Web of Conferences 31, 02014 (2018)
ICENIS 2017.

[9] Nurjanah, S., Lestari, D. S., Widyasanti, A., and Zain, S. 2015. "The Effect of Concentration and Length of Trans-esterification Time on Characteristic of FAME from Reutealis trisperma (Kemiri Sunan)." International Journal on Advanced Science Engineering Information Technology 5 (1): 52-6.

[10] Knothe, G. 2008. “'Designer' Biodiesel: Optimizing Fatty Ester Composition to Improve Fuels Properties." Energy \& Fuels 22 (2): 1358-64.

[11] Lŏpez-Ramirez, M. D., Garcia-Ventura, U. M., Barroso-Muńos, F. O., Segovia-Hemándesz, J. G., and Hemández, S. 2016. "Production of Methyl Oleate in Reactive-Separation Systems." Chem. Eng. Technol. 39 (2): 271-5.

[12] Lei, Z., Li, C., and Chen, B. 2003. "Extractive Distillation: A Review." Separation and Purification Reviews 32 (2): 121-213.

[13] Aunillah, A., and Pranowo, D. 2012. "Karakteristik Biodiesel Kemiri Sunan [Reutalis trisperma (Blanco) Airy Shaw] Menggunakan Proses Transesterifikasi Dua Tahap.” Jurnal Tanaman Industri dan Penyegar 3 (3): 193-200. 